\title{
Secondary Metabolites from the Endophytic Fungus Xylaria sp. hg1009
}

\author{
Rong Chen ${ }^{1,2} \cdot$ Jian-Wei Tang ${ }^{2,3} \cdot{\text { Xing-Ren } \mathrm{Li}^{2} \cdot \text { Miao Liu }}^{2} \cdot$ Wen-Ping Ding ${ }^{1,2} \cdot$ Yuan-Fei Zhou ${ }^{2,3} \cdot$ \\ Wei-Guang Wang ${ }^{2} \cdot$ Xue $\mathrm{Du}^{2} \cdot$ Han-Dong Sun ${ }^{2} \cdot$ Pema-Tenzin Puno ${ }^{2}$
}

Received: 23 January 2018 / Accepted: 12 March 2018/Published online: 20 March 2018

(C) The Author(s) 2018

\begin{abstract}
A detailed chemical investigation of the secondary metabolites produced by the endophytic fungus Xylaria sp. isolated from the stems of Isodon sculponeatus afforded six new compounds, xylariahgins A-F (1-6), two new natural products (7 and 8), along with two known compounds (9 and 10) (Fig. 1). The structures of all compounds were unambiguously established by analyzing their spectroscopic data or referring to pertinent literature. Compounds 1-8 were tested for their cytotoxic activity against five human tumor cell lines.
\end{abstract}

Keywords Endophytic fungus $\cdot$ Xylaria $\mathrm{sp} . \cdot$ Secondary metabolites $\cdot$ Cytotoxicity

\section{Introduction}

Endophytic fungi are microorganisms, parasitizing plants without causing any obvious disease at any specific moment of their colonizing period [1]. Although interactions between endophytes with their hosts are not fully understood in most cases, many endophytes produce bioactive secondary metabolites that may protect hosts from herbivores, plant pathogens, and abiotic stressors $[2,3]$. The bioactive secondary metabolites produced by endophytes may be useful in medicine, industry and agriculture [4-8]. In addition, plants which possess significant biological activity have the potential of harbouring endophytes with great biodiversity [9]. The genus Isodon is an abundant source of diterpenoids with diverse chemical structures, of which some ones exhibit antitumor and anti-

Electronic supplementary material The online version of this article (https://doi.org/10.1007/s13659-018-0158-x) contains supplementary material, which is available to authorized users.

Pema-Tenzin Puno

punopematenzin@mail.kib.ac.cn

1 School of Chemical Science and Technology, Yunnan University, Kunming 650091, People's Republic of China

2 State Key Laboratory of Phytochemistry and Plant Resources in West China, Kunming Institute of Botany, Chinese Academy of Sciences, Kunming 650201, People's Republic of China

3 University of Chinese Academy of Sciences, Beijing 100049, People's Republic of China inflammatory activities [10-12]. Therefore, we assumed that the secondary metabolites produced by endophytic fungi in Isodon species could be functional in biology and structural diversity. Our previous investigation had already testified that some secondary metabolites secreted by endophytic fungus from I. eriocalyx var. laxiflora possessed interesting structure and diverse bioactivities, such as penicilfuranone A isolated from Penicillium sp. sh18 [13], phomopchalasins A and B isolated from Phomopsis sp. shj2 [14] and phomopsiketones A-C isolated from Phomopsis sp. sh917 [15]. Accordingly, we have extended our attention to endophytic fungus in Isodon species. In this research, we have conducted our research with the fungus Xylaria sp., isolated from the stems of I. sculponeatus. Fungi in the genus Xylaria have been a rich source of compounds with intriguing structure, including pestalotin 4'- $O$-methyl- $\beta$-mannopyranoside and $3 S, 4 R$-(+)-4-hydroxymellein from Xylaria feejeensis [16], nigriterpenes A-F from $X$. nigripes YMJ653 [17], cytochalasin $\mathrm{Z}_{27}$ and cytochalasin $\mathrm{Z}_{28}$ from Xylaria sp. XC-16 [18].

Through OSMAC strategy analysis [19], Rice and MEA media were selected as the larger fermentation media for subsequent study. As a result, ten compounds, including six new ones, named xylariahgins A-F (1-6), two new natural products, 3-(2,3-dihydroxypropyl)-6,8-dimethoxyisocoumarin and methyl 4-(hexanoylamino) benzoate (7 and 8), and two known ones, (-)-5-carboxylmellein and 4-methoxyisoquinolin-1(2H)-one (9 and 10), were discovered from two culture extract. The isolation, structure 


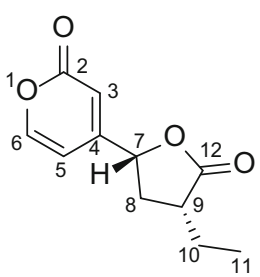

1

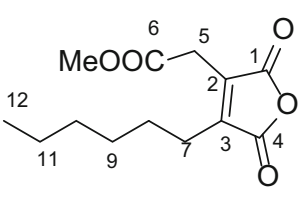

5

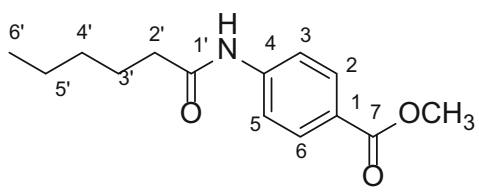

8<smiles>CCCCCCC1=C(CC(=O)O)C(=O)OC1=O</smiles>

2-carboxymethyl-

3-hexylmaleic anhydride

Fig. 1 Structures of compounds 1-10 and orthosporin dimethyl ether

elucidation and bioactivity of these compounds, are herein described (Figs. 1, 2).

\section{Results and Discussion}

On the basis of HRESIMS $\left([\mathrm{M}+\mathrm{Na}]^{+} 231.0624\right.$, calcd for 231.0628) and ${ }^{13} \mathrm{C}$ NMR data, xylariahgin $\mathrm{A}(\mathbf{1})$ has the molecular formula $\mathrm{C}_{11} \mathrm{H}_{12} \mathrm{O}_{4}$, indicating six degrees of unsaturation. Its IR absorptions at 1781 and $1663 \mathrm{~cm}^{-1}$ implied the existence of lactone and $\mathrm{C}=\mathrm{C}$ groups. The ${ }^{1} \mathrm{H}$, ${ }^{13} \mathrm{C}$ NMR and DEPT spectra revealed the presence of one methyl group, two methylenes, five methines including three olefinic methines, three quarternary carbons (two carbonyls, one olefinic group) (Table 1 ). The ${ }^{1} \mathrm{H}-{ }^{1} \mathrm{H}$ COSY spectrum of 1 exhibited the correlations of $\mathrm{H}_{3}-11 / \mathrm{H}_{2}-10 / \mathrm{H}-$ $9 / \mathrm{H}_{2}-8 / \mathrm{H}-7$. While its HMBC spectrum showed the<smiles>CC(=O)CC[C@H](O)c1ccoc(=O)c1</smiles>

3<smiles>C=C[C@H]1C[C@@](C)(C2=CC(=O)CCO2)OC1=O</smiles>

4<smiles>COc1cc2c(c(OC)c1)C(=O)OC(C[C@H](O)CO)C2</smiles>

7

9

10<smiles>COc1cc(OC)c2c(=O)oc(C[C@H](C)O)cc2c1</smiles>

Orthosporin dimethyl ether

correlations from $\mathrm{H}_{\mathrm{b}}-10\left(\delta_{\mathrm{H}} 1.53, \mathrm{~m}\right)$ to $\mathrm{C}-8$ and $\mathrm{C}-12, \mathrm{H}_{\mathrm{b}}-8$ $\left(\delta_{\mathrm{H}} 2.06, \mathrm{~m}\right)$ to $\mathrm{C}-10$ and $\mathrm{C}-12, \mathrm{H}-7\left(\delta_{\mathrm{H}} 5.28, \mathrm{dd}, 9.9,6.1\right)$ to $\mathrm{C}-12$. These results indicated that $\mathbf{1}$ has a furanone moiety. Similarly, the structure of pyrone is supported by the HMBC correlations from $\mathrm{H}-5\left(\delta_{\mathrm{H}} 6.26\right.$, dd, 5.9, 2.5) to C-6 and C-3, from H-3 $\left(\delta_{\mathrm{H}} 6.37, \mathrm{~d}, 2.5\right)$ to C-4, C-7 and C-2, from H-6 $\left(\delta_{\mathrm{H}} 8.05, \mathrm{~d}, 5.9\right)$ to C-4, C-2 and C-5 (Fig. 2). Furthermore, the HMBC correlations from $\mathrm{H}_{\mathrm{b}}-8$ to C-4, from $\mathrm{H}-3$ to $\mathrm{C}-7$ determined the direct connection of the furanone moiety with the pyrone moiety. Additionally, the key ROESY correlation between $\mathrm{H}-7$ and $\mathrm{H}-9$ supported that the H-7 and H-9 were cofacial and were arbitrarily assigned as $\beta$-oriented (Fig. 3). Therefore, the structure and relative configuration of compound $\mathbf{1}$ was determined.

Xylariahgin B (2) was obtained as colorless oil. Its IR absorptions at 3422, 2932, 1657 and $1595 \mathrm{~cm}^{-1}$ implied 


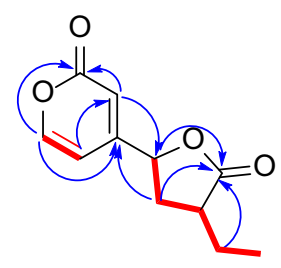

1

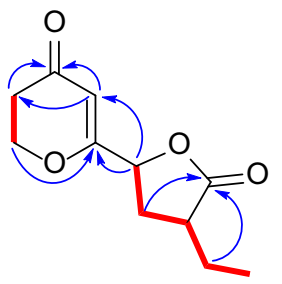

4

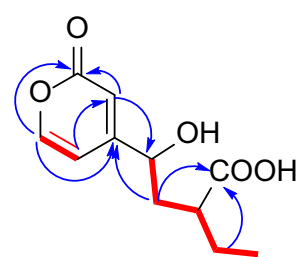

2

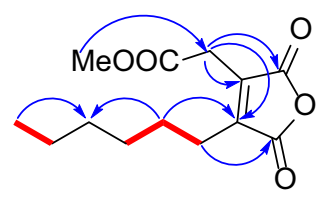

5

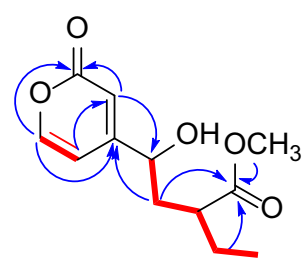

3

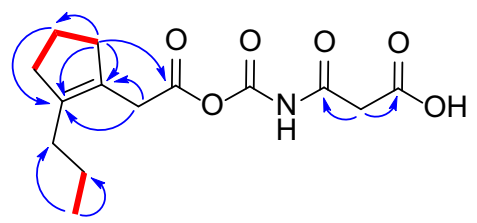

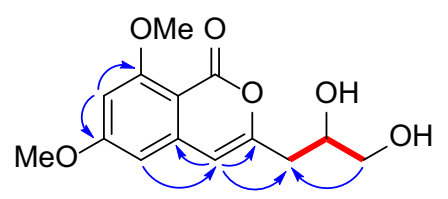

7

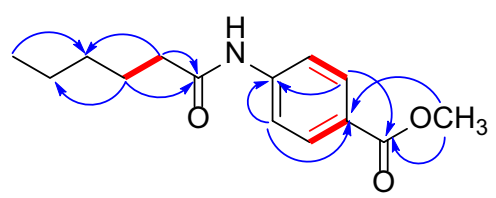

8

Fig. 2 Key HMBC (blue arrows $\mathrm{H} \rightarrow \mathrm{C}$ ), ${ }^{1} \mathrm{H}-{ }^{1} \mathrm{H}$ COSY (red lines) correlations of 1-8

the presence of $\mathrm{OH}, \mathrm{COOH}$, lactone and $\mathrm{C}=\mathrm{C}$ groups. Its HRESIMS displayed a molecular ion peak $[\mathrm{M}+\mathrm{Na}]^{+}$at $\mathrm{m} /$ $z$ 249.0730 (calcd for 249.0733), corresponding to the molecular formula $\mathrm{C}_{11} \mathrm{H}_{14} \mathrm{O}_{5}$. Comparison of its ${ }^{1} \mathrm{H}$ and ${ }^{13} \mathrm{C}$ NMR spectra (Table 1) with those of $\mathbf{1}$ indicated that these two compounds were closely related. The only difference was that $\mathbf{2}$ had less one degree of unsaturation than 1. Furthermore, the HMBC correlations from $\mathrm{H}_{3}-11\left(\delta_{\mathrm{H}}\right.$ $0.96, \mathrm{t}, 7.4)$ to $\mathrm{C}-10$ and $\mathrm{C}-9, \mathrm{H}_{2}-10\left(\delta_{\mathrm{H}} 1.70, \mathrm{~m} ; 1.58, \mathrm{~m}\right)$ to $\mathrm{C}-9, \mathrm{C}-8$ and $\mathrm{C}-12, \mathrm{H}_{2}-8\left(\delta_{\mathrm{H}} 2.13, \mathrm{~m} ; 1.96, \mathrm{~m}\right)$ to $\mathrm{C}-10$, C-9, C-12 and C-4 suggested that the furanone ring of $\mathbf{1}$ was opened in 2 (Fig. 2). Above data together with ${ }^{1} \mathrm{H}-{ }^{1} \mathrm{H}$ COSY and other key HMBC correlations from H-5 $\left(\delta_{\mathrm{H}}\right.$ 6.34 , dd, $5.8,2.4)$ to $\mathrm{C}-6$ and $\mathrm{C}-3$, from $\mathrm{H}-3\left(\delta_{\mathrm{H}} 6.59\right.$, d, $2.4)$ to $\mathrm{C}-4, \mathrm{C}-7$ and $\mathrm{C}-2$, from $\mathrm{H}-6\left(\delta_{\mathrm{H}} 7.77, \mathrm{~d}, 5.8\right)$ to $\mathrm{C}-4$, $\mathrm{C}-2$ and $\mathrm{C}-5$ elucidated the planar structure of 2 . The relative configuration of $\mathbf{2}$ was determined by a hydrolysis reaction of $\mathbf{1}$. 1 was exposed to $\mathrm{K}_{2} \mathrm{CO}_{3} / \mathrm{MeOH}$ at room temperature for $4 \mathrm{~h}$, with HPLC-DAD analysis detecting conversion to 2 (Fig. S31).

Xylariahgin C (3) was found by HRESIMS $\left([\mathrm{M}+\mathrm{Na}]^{+}\right.$ $\mathrm{m} / \mathrm{z} 263.0884$, calcd for 263.0890) to possess the molecular formula $\mathrm{C}_{12} \mathrm{H}_{16} \mathrm{O}_{6}$ as determined. Its IR absorptions at 3395, 1732 and $1660 \mathrm{~cm}^{-1}$ implied the presence of $\mathrm{OH}$, lactone and $\mathrm{C}=\mathrm{C}$ groups. The ${ }^{1} \mathrm{H}$ and ${ }^{13} \mathrm{C}$ NMR spectra
(Table 1) of $\mathbf{3}$ were similar to those of $\mathbf{2}$ except that there was one more methoxy group in compound $\mathbf{3}$. The HMBC correlation from $\mathrm{CH}_{3} \mathrm{O}-12$ to $\mathrm{C}-12$ verified the presence of methoxy signal. The ${ }^{1} \mathrm{H}-{ }^{1} \mathrm{H}$ COSY correlations of $\mathrm{H}_{3}-11 /$ $\mathrm{H}_{2}-10 / \mathrm{H}-9 / \mathrm{H}_{2}-8 / \mathrm{H}-7$ and $\mathrm{H}-5 / \mathrm{H}-6$, coupled with the key HMBC correlations from $\mathrm{H}-8\left(\delta_{\mathrm{H}} 2.15, \mathrm{~m} ; 1.93, \mathrm{~m}\right)$ to C-4 and $\mathrm{C}-12$, and from $\mathrm{H}-10\left(\delta_{\mathrm{H}} 1.62, \mathrm{~m}\right)$ to $\mathrm{C}-12$ determined the structure of 3 (Fig. 2). Similarly, the relative configuration of $\mathbf{3}$ was also supported by the hydrolysis reaction of 1. Similar treatment of $\mathbf{1}$ with $\mathrm{K}_{2} \mathrm{CO}_{3} / \mathrm{MeOH}$ resulted in conversion to $\mathbf{2}$ and $\mathbf{3}$, simultaneously. Therefore, the relative configuration of $\mathbf{3}$ was confirmed (Fig. S31).

Xylariahgin D (4) was found to have the molecular formula $\mathrm{C}_{11} \mathrm{H}_{14} \mathrm{O}_{4}$ established by HRESIMS at $\mathrm{m} / \mathrm{z}$ $233.0784[\mathrm{M}+\mathrm{Na}]^{+}$(calcd for 233.0784), indicating five degrees of unsaturation. Its IR absorptions at 1779 and $1671 \mathrm{~cm}^{-1}$ implied the presence of lactone and $\mathrm{C}=\mathrm{C}$ groups. The ${ }^{1} \mathrm{H}$ NMR spectrum (Table 1) showed typical signals assignable to one methyl at $\delta_{\mathrm{H}}(1.01, \mathrm{t}, 7.5)$, one olefinic methine at $\delta_{\mathrm{H}}(5.61, \mathrm{~s})$. The ${ }^{13} \mathrm{C}$ NMR and DEPT spectra of $\mathbf{4}$ displayed resonances for 11 carbons, ascribed to one methyls, four methylenes (including one oxygenated methylene), three methines (one olefinic, one oxygenated methine), and three quaternary carbons (two carbonyls). These data accounted for all ${ }^{1} \mathrm{H}$ and ${ }^{13} \mathrm{C}$ NMR resonances 
Table 1 NMR data of $\mathbf{1 - 4}(\delta$ in ppm, $J$ in $\mathrm{Hz})$

\begin{tabular}{|c|c|c|c|c|c|c|c|c|}
\hline \multirow[t]{2}{*}{ No } & \multicolumn{2}{|l|}{$1^{\mathrm{a}}$} & \multicolumn{2}{|l|}{$2^{\mathrm{b}}$} & \multicolumn{2}{|l|}{$3^{\mathrm{c}}$} & \multicolumn{2}{|l|}{$4^{\mathrm{b}}$} \\
\hline & $\delta_{\mathrm{H}}$ & $\delta_{\mathrm{C}}$ & $\delta_{\mathrm{H}}$ & $\delta_{\mathrm{C}}$ & $\delta_{\mathrm{H}}$ & $\delta_{\mathrm{C}}$ & $\delta_{\mathrm{H}}$ & $\delta_{\mathrm{C}}$ \\
\hline \multicolumn{9}{|l|}{1} \\
\hline 2 & & $178.3, \mathrm{~s}$ & & $180.4, \mathrm{~s}$ & & 178.6, s & & 171.6, s \\
\hline 3 & $6.37,1 \mathrm{H}(\mathrm{d}, 2.5)$ & 115.1, d & $6.59,1 \mathrm{H}(\mathrm{d}, 2.4)$ & 112.7, d & $6.30,1 \mathrm{H}(\mathrm{d}, 2.5)$ & $113.5, \mathrm{~d}$ & $5.61,1 \mathrm{H}(\mathrm{s})$ & 103.7, d \\
\hline 4 & & $165.2, \mathrm{~s}$ & & $171.3, \mathrm{~s}$ & & 171.2, s & & 191.6, s \\
\hline 5 & $6.26,1 \mathrm{H}(\mathrm{dd}, 5.9,2.5)$ & 117.7, d & $\begin{array}{l}\text { 6.34, } 1 \mathrm{H}(\mathrm{dd}, 5.8 \text {, } \\
2.4)\end{array}$ & 116.7, d & $\begin{array}{l}6.17,1 \mathrm{H}(\mathrm{dd}, 5.8 \text {, } \\
2.5)\end{array}$ & $117.4, \mathrm{~d}$ & $2.60,2 \mathrm{H}(\mathrm{m})$ & $36.1, \mathrm{t}$ \\
\hline 6 & $8.05,1 \mathrm{H}(\mathrm{d}, 5.9)$ & $156.9, \mathrm{~d}$ & $7.77,1 \mathrm{H}(\mathrm{d}, 5.8)$ & 155.6, d & $7.97,1 \mathrm{H}(\mathrm{d}, 5.8)$ & $156.3, \mathrm{~d}$ & $4.56,2 \mathrm{H}(\mathrm{m})$ & $68.7, \mathrm{t}$ \\
\hline 7 & $5.28,1 \mathrm{H}(\mathrm{dd}, 9.9,6.1)$ & $75.4, \mathrm{~d}$ & $\begin{array}{l}\text { 4.56, } 1 \mathrm{H}(\mathrm{dd}, 8.6 \text {, } \\
4.2)\end{array}$ & $69.7, \mathrm{~d}$ & $4.53,1 \mathrm{H}(\mathrm{m})$ & $69.1, \mathrm{~d}$ & $\begin{array}{l}4.80,1 \mathrm{H}(\mathrm{dd}, 9.5 \text {, } \\
6.5)\end{array}$ & $75.0, d$ \\
\hline \multirow[t]{2}{*}{8} & $2.82,1 \mathrm{H}(\mathrm{m})$ & $32.8, \mathrm{t}$ & $2.13,1 \mathrm{H}(\mathrm{m})$ & $36.8, \mathrm{t}$ & $2.15,1 \mathrm{H}(\mathrm{m})$ & $37.7, \mathrm{t}$ & $2.62,1 \mathrm{H}(\mathrm{m})$ & $32.3, \mathrm{t}$ \\
\hline & $2.06,1 \mathrm{H}(\mathrm{m})$ & & $1.96,1 \mathrm{H}(\mathrm{m})$ & & $1.93,1 \mathrm{H}(\mathrm{m})$ & & $1.96,1 \mathrm{H}(\mathrm{m})$ & \\
\hline 9 & $2.83,1 \mathrm{H}(\mathrm{m})$ & $41.9, \mathrm{~d}$ & $2.49,1 \mathrm{H}(\mathrm{m})$ & $44.3, \mathrm{~d}$ & $2.55,1 \mathrm{H}(\mathrm{m})$ & $44.3, d$ & $2.61,1 \mathrm{H}(\mathrm{m})$ & $41.3, \mathrm{~d}$ \\
\hline \multirow[t]{2}{*}{10} & $1.86,1 \mathrm{H}(\mathrm{m})$ & $23.9, \mathrm{t}$ & $1.70,1 \mathrm{H}(\mathrm{m})$ & $26.1, \mathrm{t}$ & $1.62,2 \mathrm{H}(\mathrm{m})$ & $26.1, \mathrm{t}$ & $1.95,1 \mathrm{H}(\mathrm{m})$ & $23.5, \mathrm{t}$ \\
\hline & $1.53,1 \mathrm{H}(\mathrm{m})$ & & $1.58,1 \mathrm{H}(\mathrm{m})$ & & & & $1.55,1 \mathrm{H}(\mathrm{m})$ & \\
\hline 11 & $0.99,3 \mathrm{H}(\mathrm{t}, 7.5)$ & 11.7, q & $0.96,3 \mathrm{H}(\mathrm{t}, 7.4)$ & $11.5, \mathrm{q}$ & $0.88,3 \mathrm{H}(\mathrm{t}, 7.4)$ & 11.7, q & $1.01,3 \mathrm{H}(\mathrm{t}, 7.5)$ & $11.6, \mathrm{q}$ \\
\hline 12 & & 177.8, s & & $179.9, \mathrm{~s}$ & & $176.3, \mathrm{~s}$ & & 177.2, s \\
\hline 12-OMe & & & & & $3.60,3 \mathrm{H}(\mathrm{s})$ & $51.7, \mathrm{q}$ & & \\
\hline
\end{tabular}

The assignments were based on HSQC, ${ }^{1} \mathrm{H}-{ }^{1} \mathrm{H}$ COSY, and HMBC experiments

${ }^{\mathrm{a} 1} \mathrm{H}$ and ${ }^{13} \mathrm{C}$ NMR data were recorded at $500 \mathrm{MHz}$ and $125 \mathrm{MHz}$ in Acetone- $d_{6}$, respectively

${ }^{\mathrm{b} 1} \mathrm{H}$ and ${ }^{13} \mathrm{C}$ NMR data were recorded at $500 \mathrm{MHz}$ and $125 \mathrm{MHz}$ in $\mathrm{CDCl}_{3}$, respectively

${ }^{\mathrm{c} 1} \mathrm{H}$ and ${ }^{13} \mathrm{C}$ NMR data were recorded at $600 \mathrm{MHz}$ and $150 \mathrm{MHz}$ in Acetone- $d_{6}$, respectively

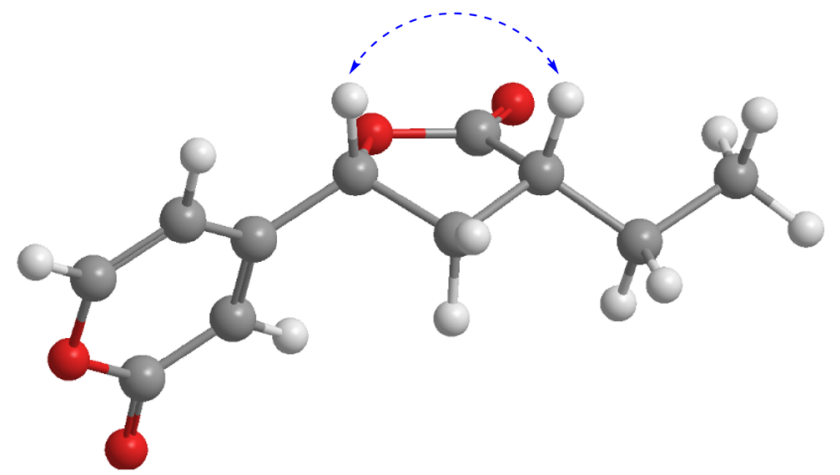

Fig. 3 ROESY correlation (blue dashed double-headed arrow) of $\mathbf{1}$

and indicated 4 is a polyketide. The ${ }^{1} \mathrm{H}-{ }^{1} \mathrm{H}$ COSY correlations of $\mathrm{H}_{2}-5 / \mathrm{H}_{2}-6$, suggested the connection from C-5 to C-6. The detailed planar structure of 4 was further constructed by the HMBC correlations. The HMBC correlations from $\mathrm{H}-3\left(\delta_{\mathrm{H}} 5.61, \mathrm{~s}\right)$ to $\mathrm{C}-2, \mathrm{C}-4$ and $\mathrm{C}-5, \mathrm{H}_{2}-5\left(\delta_{\mathrm{H}}\right.$ $2.60, \mathrm{~m})$ to $\mathrm{C}-4$, and $\mathrm{H}_{2}-6\left(\delta_{\mathrm{H}} 4.56, \mathrm{~m}\right)$ to $\mathrm{C}-4, \mathrm{C}-2$, indicated the presence of pyrone. In the HMBC spectrum of $\mathbf{4}$, correlations from $\mathrm{H}_{2}-8\left(\delta_{\mathrm{H}} 2.62, \mathrm{~m} ; 1.96, \mathrm{~m}\right)$ to $\mathrm{C}-7, \mathrm{C}-12$ and $\mathrm{C}-10$, coupled with the ${ }^{1} \mathrm{H}-{ }^{1} \mathrm{H}$ COSY correlations of $\mathrm{H}-7 / \mathrm{H}_{2}-8 / \mathrm{H}-9 / \mathrm{H}_{2}-10 / \mathrm{H}_{3}-11$ proved the presence of furanone moiety (Fig. 2).
In 4 , the pyrone moiety with the connection to furanone moiety was confirmed from key HMBC correlations from H-7 to C-2, C-3, and H-8 to C-2. Herein, the structure of pyranone derivative was elucidated. In addition, there was no obvious ROESY correlation of $\mathrm{H}-7 / \mathrm{H}-9$, indicative of their opposite oriented, and $\mathrm{H}-7$ were arbitrarily assigned as $\beta$-oriented, $\mathrm{H}-9$ were arbitrarily assigned as $\alpha$-oriented.

Xylariahgin E (5) was isolated as yellowish oil, and its molecular formula was established to be $\mathrm{C}_{13} \mathrm{H}_{18} \mathrm{O}_{5}$ by HRESIMS at $m / z 253.1081[\mathrm{M}-\mathrm{H}]^{-}$(calcd for 253.1087). Its IR absorptions at 2928, 1773 and $1745 \mathrm{~cm}^{-1}$ implied the presence of lactone and $\mathrm{C}=\mathrm{C}$ groups. Comparison of the ${ }^{1} \mathrm{H}$ and ${ }^{13} \mathrm{C}$ NMR data (Table 2) of compound 5 with that of 2-carboxymethyl-3-hexylmaleic anhydride indicated that both compounds had identical skeleton and substitution patterns, differing only in that compound $\mathbf{5}$ was esterified in C-6 [20]. This conclusion was verified by the key HMBC correlations from $\mathrm{H}_{2}-5\left(\delta_{\mathrm{H}} 3.52, \mathrm{~s}\right)$ to $\mathrm{C}-1$ and $\mathrm{C}-6$, from $\mathrm{H}_{2}-7\left(\delta_{\mathrm{H}} 2.48, \mathrm{~m}\right)$ to $\mathrm{C}-4$, and from $6-\mathrm{OMe}\left(\delta_{\mathrm{H}}\right.$ 3.75 , s) to C-6 (Fig. 2). Herein, 5 was assigned as a new dialkylmaleic anhydride devirative.

Xylariahgin F (6) was obtained as a yellowish amorphous powder and gave a HRESIMS ion peak at $\mathrm{m} / \mathrm{z}$ $320.1108\left([\mathrm{M}+\mathrm{Na}]^{+}\right.$, calcd for 320.1105), which 


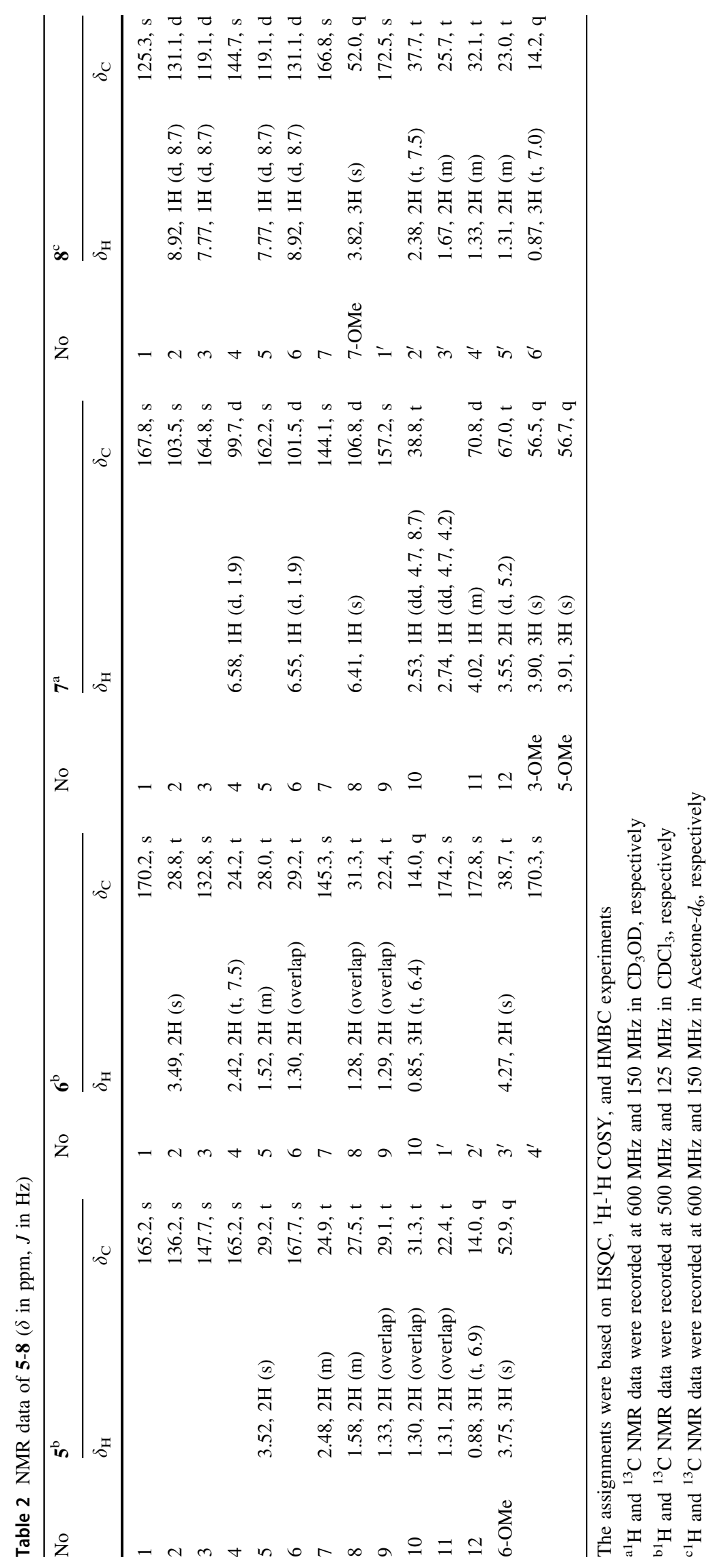


corresponded to a molecular formula of $\mathrm{C}_{14} \mathrm{H}_{19} \mathrm{NO}_{6}$ with six degrees of unsaturation. Its IR absorptions at 2928 , 1717 and $1429 \mathrm{~cm}^{-1}$ implied the presence of $\mathrm{COOH}, \mathrm{C}=\mathrm{O}$ and $\mathrm{C}=\mathrm{C}$ groups. The ${ }^{1} \mathrm{H}$ and ${ }^{13} \mathrm{C}$ NMR spectra (Table 2) exhibited 14 carbon resonances including one methyl $\left(\delta_{\mathrm{C}}\right.$ 14.0), seven methylenes $\left(\delta_{\mathrm{C}} 22.4,24.2,28.0,28.8,29.2\right.$, 31.3 , and 38.7$)$, two olefinic quaternary carbons $\left(\delta_{\mathrm{C}} 132.8\right.$, $145.3)$, four carbonyl carbons $\left(\delta_{\mathrm{C}} 170.2,170.3,172.8\right.$, and 174.2). The ${ }^{1} \mathrm{H}^{-}{ }^{1} \mathrm{H}$ COSY correlations of $\mathrm{H}_{2}-4 / \mathrm{H}_{2}-5 / \mathrm{H}_{2}-6$, and $\mathrm{H}_{2}-9 / \mathrm{H}_{3}-10$ were observed, HMBC correlations from $\mathrm{H}_{3}-10\left(\delta_{\mathrm{H}} 0.85, \mathrm{t}, 6.4\right)$ to $\mathrm{C}-9$ and $\mathrm{C}-8$, from $\mathrm{H}_{2}-4\left(\delta_{\mathrm{H}} 2.42\right.$, t, 7.5) to C-3, C-5 and C-7, from H-5 $\left(\delta_{\mathrm{H}} 1.52, \mathrm{~m}\right)$ to C-7, from $\mathrm{H}-2\left(\delta_{\mathrm{H}} 3.49, \mathrm{~s}\right)$ to $\mathrm{C}-1, \mathrm{C}-3$ and $\mathrm{C}-7$ suggested compound $\mathbf{6}$ was a 2-propylcyclopenteneacetic acid derivative. The HMBC correlations of $\mathrm{H}_{2}-3^{\prime}\left(\delta_{\mathrm{H}} 4.27, \mathrm{~s}\right)$ with $\mathrm{C}-2^{\prime}$ and $\mathrm{C}-4^{\prime}$, revealed compound $\mathbf{6}$ was a propanedioic acid derivative (Fig. 2). Herein, the structure of two units was elucidated, and suggested compound $\mathbf{6}$ was a monocyclic polyketide derivative. The rest of units and the connections of the all the units in $\mathbf{6}$ was supported by $\mathrm{EI}^{+}$ mass spectrum. In $\mathrm{EI}^{+}$mass spectrum, it seemed certain that $m / z 297$ is the molecular ion. The spectrum displayed the fragment ion $\mathrm{m} / \mathrm{z}, 252$ due to the loss of $\mathrm{COOH}$ on the base of the molecular ion. And the ion at $\mathrm{m} / z 209$ was strong in spectrum, probably was a daughter of $m / z 251$ via loss of $\mathrm{C}_{2} \mathrm{H}_{2} \mathrm{O}$. The major fragment ions at $\mathrm{m} / z \mathrm{z} 123,169$, 195 which were due to the processes $\left(\mathrm{M}^{+}\right.$$\left.\mathrm{COOCONHCOCH}{ }_{2} \mathrm{COOH}\right), \quad\left(\mathrm{M}^{+}-\mathrm{CONHCOCH}_{2-}\right.$ $\left.\mathrm{COOH}+2 \mathrm{H}^{+}\right), \quad\left(\mathrm{M}^{+}-\mathrm{NHCOCH}_{2} \mathrm{COOH}\right)$, respectively. Then the peak at $m / z, 181$ was a daughter of $m / z, 195$ by means of losing $\mathrm{CH}_{2}$. Similarly, the ion at $\mathrm{m} / z 137$ was a daughter of $\mathrm{m} / \mathrm{z}, 181$ via loss $\mathrm{CO}_{2}$. Herein, the ion $\mathrm{m} / \mathrm{z}$ at 123, 137, 181, 252, 251, 169, and 209 in $\mathrm{EI}^{+}$mass spectrum proved the presence of the fragment ion I-VII (Fig. S61). Therefore, the structure of compound $\mathbf{6}$ was elucidated.

Compound 7 had a molecular formula of $\mathrm{C}_{14} \mathrm{H}_{16} \mathrm{O}_{6}$ based on HRESIMS $\left([\mathrm{M}+\mathrm{Na}]^{+} \mathrm{m} / \mathrm{z}, 303.0838\right.$, calcd for 303.0839). Its IR absorptions at 3416, 1711, 1602, 1570, 1457 and $1429 \mathrm{~cm}^{-1}$ implied the presence of $\mathrm{OH}$, lactone and phenyl groups. Comparison of the ${ }^{1} \mathrm{H}$ and ${ }^{13} \mathrm{C}$ NMR data (Table 2) of compound 7 with that of orthosporin dimethyl ether indicated that both compounds had identical skeletons and substitution patterns, differing only in that compound 7 was hydroxylated at C-12 rather than a methyl group in orthosporin dimethyl ether [21, 22]. This conclusion was verified by the $\mathrm{HMBC}$ correlation from $\mathrm{H}_{2}-12$ $\left(\delta_{\mathrm{H}} 3.55, \mathrm{~d}, 5.2\right)$ to $\mathrm{C}-11$, and the ${ }^{1} \mathrm{H}-{ }^{1} \mathrm{H}$ COSY correlations of $\mathrm{H}_{\mathrm{a}}-10 / \mathrm{H}-11 / \mathrm{H}_{2}-12$ (Fig. 2). Accordingly, the planar structure of compound 7 was elucidated. For its absolute configuration, it was hardly to identify the configuration of $7([\alpha]-6.7, c 0.14, \mathrm{MeOH})$ by comparison with the values of specific rotation of orthosporin dimethyl ether $([\alpha]$
$+18.9, c 0.03, \mathrm{MeOH})$ on account of the values of specific rotation was too small to discriminate whether it was experimental error or not [15]. Morover, 7 was further subjected to the chiral chromatographic column (DAICEL AD-RH) $(4.6 \mathrm{~mm} \times 250 \mathrm{~mm})$ to exclude the possibility of racemate. Unfortunately, studies about the absolute configuration of 7 was restricted due to the sample shortage $(1.1 \mathrm{mg})$, therefore, the configuration of C-11 couldn't be determined under the current situation. Consequently, 7 was named 3-(2,3-dihydroxypropyl)-6,8-dimethoxyisocoumarin, and defined as a new natural product, previously reported as a reactant for the total synthesis of desmethyldiaportinol [23].

Compound $\mathbf{8}$ was obtained as a yellowish solid. Its IR absorptions at 1720, 1664, 1601, 1534 and $1407 \mathrm{~cm}^{-1}$ implied the presence of $\mathrm{C}=\mathrm{O}$ and phenyl groups. It had the molecular formula of $\mathrm{C}_{14} \mathrm{H}_{19} \mathrm{NO}_{3}$, established by HRESIMS $\left([\mathrm{M}+\mathrm{H}]^{+}\right.$250.1439, calcd for $\mathrm{C}_{14} \mathrm{H}_{20} \mathrm{NO}_{3}$, 250.1438) with six degrees of unsaturation. The ${ }^{1} \mathrm{H}$ and ${ }^{13} \mathrm{C}$ NMR data (Table 2) of $\mathbf{8}$ revealed the presence of one methyl, one methoxy group, four methylenes, four methines, and four quaternary carbons. All the above data suggested that $\mathbf{8}$ is a $p$-substituted phenyl derivative containing one nitrogen. The HMBC correlations from $\mathrm{H}_{2}-2^{\prime}\left(\delta_{\mathrm{H}} 2.38\right.$, t, 7.5) to $\mathrm{C}-4^{\prime}$ and $\mathrm{C}-1^{\prime}$, from $\mathrm{H}_{2}-3^{\prime}\left(\delta_{\mathrm{H}} 1.67, \mathrm{~m}\right)$ to $\mathrm{C}-5^{\prime}$ and $\mathrm{C}-1^{\prime}$, from $\mathrm{H}-6^{\prime}\left(\delta_{\mathrm{H}} 0.87, \mathrm{t}, 7.0\right)$ to $\mathrm{C}-5^{\prime}$ and $\mathrm{C}-4^{\prime}$, coupled with the $\mathrm{H}^{1}-\mathrm{H}^{1} \mathrm{COSY}$ correlation of $\mathrm{H}_{2}-2^{\prime} / \mathrm{H}_{2}-3^{\prime}$ proved the presence of the hexanamide group. Furthermore, the HMBC spectrum showed the correlations from $\mathrm{H}-3\left(\delta_{\mathrm{H}}\right.$ 7.77, d, 8.7) to $\mathrm{C}-1$, from $\mathrm{H}-2\left(\delta_{\mathrm{H}} 8.92, \mathrm{~d}, 8.7\right)$ to $\mathrm{C}-4$ and C-7, from $\mathrm{CH}_{3} \mathrm{O}-7\left(\delta_{\mathrm{H}} 3.82\right.$, s) to $\mathrm{C}-7$ and $\mathrm{C}-1$, corresponding with the $\mathrm{H}^{1}-\mathrm{H}^{1}$ COSY correlation of $\mathrm{H}-2 / \mathrm{H}-3$ established the $p$-substituted phenyl with methoxycarbonyl group (Fig. 2). Herein, the structure of $\mathbf{8}$ was elucidated, and named as methyl 4-(hexanoylamino) benzoate. 8 was defined as a new natural product, previously reported as a reactant for the preparation of oxindole hydrazide modulators of protein tyrosine phosphatases [24].

The structures of known compounds (9 and 10) were identified by comparison of their spectroscopic data with the literature as (-)-5-carboxylmellein (9) [25], 4-methoxyisoquinolin-1(2H)-one (10) [26], respectively.

Compounds 1-8 were tested for their cytotoxicity against HL-60, A-549, SMMC-7721, MCF-7, and SW-480 human tumor cell lines by MTS methods using cisplatin and paclitaxel as positive controls. Neither of them showed cytotoxic activity against all cell lines. 


\section{Experimental}

\subsection{General}

Optical rotations were measured in $\mathrm{MeOH}$ with JASCO P-1020 polarimeters. 1D and 2D NMR spectra were recorded on Advance III 500 or 600 spectrometers using pyridine- $d_{5}$ as the internal standard. Chemical shifts $(\delta)$ are expressed in ppm relative to the pyridine- $d_{5}$ signals. HRESIMS was performed on an API QSTAR spectrometer. UV spectra were obtained on a Shimadzu UV-2401PC spectrophotometer. IR spectra were obtained on a Bruker Tensor-27 FT-IR spectrometer using $\mathrm{KBr}$ pellets. Column chromatography (CC) was performed with silica gel (100-200 mesh; Qingdao Marine Chemical, Inc., Qingdao, People's Republic of China), MCI gel (CHP20P, 75-150 $\mu \mathrm{m}$, Mitsubishi Chemical Corporation, Tokyo, Japan). Semi-preparative HPLC was performed on an Agilent 1200 liquid chromatograph with a Zorbax SB-C18 $(9.4 \mathrm{~mm} \times 250 \mathrm{~mm})$ column. Fractions were monitored by thin layer chromatography, spots were visualized by UV light (254 $\mathrm{nm}$ and $365 \mathrm{~nm}$ ) and by heating silica gel plates sprayed with $10 \% \mathrm{H}_{2} \mathrm{SO}_{4}$ in EtOH. All solvents used in column chromatography were distilled including petroleum ether.

\subsection{Fungal Material and Identification}

The fungal strain of Xylaria sp. hg1009 was isolated from fresh stems of I. sculponeatus collected from Weishan, DaLi, People's Republic of China, in December 2012. Fungal identification was based on sequence analysis (GenBank Accession No. MG739623) of internal transcribed spacer (ITS) regions of the rDNA.

\subsection{Fermentation, Extraction and Isolation}

The fungus was cultivated in solid rice medium in 135 Fernbach flasks $(500 \mathrm{~mL}, 60 \mathrm{~mL}$ distilled water was added to $80 \mathrm{~g}$ rice and kept overnight before autoclaving) for 40 days at $28{ }^{\circ} \mathrm{C}$ in a static incubator. The fungus was cultivated in $200 \mathrm{~mL}$ MEA liquid medium in 58 Erlenmeyer flasks $(500 \mathrm{~mL})$ for two weeks at $28{ }^{\circ} \mathrm{C}$ on a rotary shaker at $180 \mathrm{rpm}$.

The rice medium was overlaid and extracted with $70 \%$ aqueous acetone. The solvent was then evaporated in vacuo to afford a crude extract $(80 \mathrm{~g})$. The extraction was subjected to column chromatography on silica gel with a $\mathrm{CHCl}_{3} / \mathrm{Me}_{2} \mathrm{CO}$ gradient system (1:0, 9:1, 8:2, 7:3, 6:4, 1:1, $0: 1)$ to yield seven fractions, A-G. Fraction A $\left(\mathrm{CHCl}_{3} /\right.$ $\mathrm{Me}_{2} \mathrm{CO} 1: 0,12 \mathrm{~g}$ ) was subjected to column chromatography on silica gel with a petroleum ether $/ \mathrm{CH}_{3} \mathrm{CH}_{2} \mathrm{OAc}$ gradient system (from 10:1 to 0:1) to afford fractions A1A9, fraction A7 was purified by semipreparative HPLC to yield $1(25 \mathrm{mg})$, fraction A8 was purified by semipreparative HPLC to yield $\mathbf{9}(2.3 \mathrm{mg})$ and $\mathbf{1 0}(1.9 \mathrm{mg})$.

Fraction $\mathrm{B} \quad\left(\mathrm{CHCl}_{3} / \mathrm{Me}_{2} \mathrm{CO} \quad 9: 1,19 \mathrm{~g}\right)$ was chromatographed on RP-18 with $\mathrm{MeOH} / \mathrm{H}_{2} \mathrm{O}$ (30:70, 40:60, $50: 50,60: 40,70: 30,100: 0)$ to obtain B1-B11, B3 $(65 \mathrm{mg})$ and B4 $(80 \mathrm{mg}$ )was purified by semipreparative HPLC to afford $2(5.9 \mathrm{mg}), \mathbf{3}(30 \mathrm{mg})$, and $7(1.1 \mathrm{mg})$, respectively. B8 (1.2 g) chromatographed on a silica gel column with a petroleum ether/ $\mathrm{Me}_{2} \mathrm{CO}$ gradient system (from 20:1 to 1:1) to afford fractions B8-1 to B8-7. Fraction B8-5 was purified by preparative HPLC to yield $4(3.5 \mathrm{mg})$. Fraction C $\left(\mathrm{CHCl}_{3} / \mathrm{Me}_{2} \mathrm{CO} 8: 2,15 \mathrm{~g}\right)$ was purified by silica gel column with a petroleum ether $/ \mathrm{CH}_{3} \mathrm{CH}_{2} \mathrm{OAc}$ gradient system (from 10:1 to 1:2) to afford fractions C1-C9. Fraction C6 was purified by preparative HPLC yield subfractions C6-1 to C6-5, then subfraction C6-2 were purified by semipreparative HPLC to yield $6(60 \mathrm{mg})$.

The MEA culture broth was extracted with EtOAc 3 times to yield a crude extract $(3.2 \mathrm{~g})$. The extraction was subjected to RP-18 with $\mathrm{MeOH} / \mathrm{H}_{2} \mathrm{O}(20: 80,30: 70,50: 50$, 70:30, and 100:0) to yield five fractions, A-E. Fraction B $(0.6 \mathrm{~g})$ was chromatographed on a silica gel column with a petroleum ether $/ \mathrm{Me}_{2} \mathrm{CO}$ gradient system (from 10:1 to 0:1) to afford fractions B1-B3. Fraction B1 was subsequently purified by semipreparative HPLC to yield $\mathbf{5}(1.4 \mathrm{mg})$ and $8(2.1 \mathrm{mg})$.

\subsection{The Cytotoxicity Assay}

The human tumor cell lines HL-60, SMMC-7721, A-549, MCF-7, and SW-480 were used in the cytotoxic assay. These cell lines were obtained from ATCC (Manassas, VA, USA). Cells were cultured in RMPI-1640 or DMEM medium (Biological Industries, Kibbutz Beit-Haemek, Israel) supplemented with $10 \%$ fetal bovine serum (Biological Industries) at $37^{\circ} \mathrm{C}$ in a humidified atmosphere with $5 \% \mathrm{CO}_{2}$. The cytotoxicity assay was evaluated by the 3-(4,5-dimethylthiazol-2-yl)-5-(3-carboxymethoxyphenyl)2-(4-sulfophenyl)-2H-tetrazolium, inner salt (MTS) (Promega, Madison, WI, USA) assay [27]. Briefly, cells were seeded into each well of a 96-well cell culture plate. After $12 \mathrm{~h}$ of incubation at $37^{\circ} \mathrm{C}$, the test compound $(40 \mu \mathrm{M})$ was added. After incubated for $48 \mathrm{~h}$, cells were subjected to the MTS assay $[28,29]$. Compounds with a growth inhibition rate of $50 \%$ were further evaluated at concentrations of $0.064,0.32,1.6,8$, and $40 \mu \mathrm{M}$ in triplicate, with cisplatin and paclitaxel (Sigma, St. Louis, MO, USA) as positive controls. The $\mathrm{IC}_{50}$ value of each compound was calculated with Reed and Muench's method [30].

Xylariahgin A (1) yellow oil. $[\alpha]_{\mathrm{D}}^{23}-56.9$ (c 0.18 , $\mathrm{MeOH}), \mathrm{UV}(\mathrm{MeOH}) \lambda_{\max }(\log \varepsilon) 414$ (1.70), 327 (2.48), 
248 (3.97), 207 (3.86) nm, IR (KBr) $v_{\max } 2967,2878,1781$, 1663, 1623, 1414, 1386, 1342, 1153, 1029, 956, 931, $871 \mathrm{~cm}^{-1}$. ESIMS $\mathrm{m} / \mathrm{z} 231[\mathrm{M}+\mathrm{Na}]^{+}$, HRESIMS $\mathrm{m} / \mathrm{z}$ $231.0624[\mathrm{M}+\mathrm{Na}]^{+}$(calcd for $\mathrm{C}_{11} \mathrm{H}_{12} \mathrm{O}_{4} \mathrm{Na} 231.0628$ ). ${ }^{1} \mathrm{H}$ NMR (Acetone- $d_{6}, 500 \mathrm{MHz}$ ) and ${ }^{13} \mathrm{C}$ NMR (Acetone- $d_{6}$, $125 \mathrm{MHz}$ ), see Table 1.

Xylariahgin B (2) colorless oil. $[\alpha]_{\mathrm{D}}^{20}-20.0(c 0.18$, $\mathrm{MeOH}), \mathrm{UV}(\mathrm{MeOH}) \lambda_{\max }(\log \varepsilon) 248$ (3.97), 208 (3.83) nm, IR (KBr) $v_{\max } 3422,2932,1657,1595,1422,1384$, 1328, 1236, $1103,935,874 \mathrm{~cm}^{-1}$. ESIMS $\mathrm{m} / z, 249$ $[\mathrm{M}+\mathrm{Na}]^{+}$, HRESIMS $\mathrm{m} / z 249.0730[\mathrm{M}+\mathrm{Na}]^{+}$(calcd for $\left.\mathrm{C}_{11} \mathrm{H}_{14} \mathrm{O}_{5} \mathrm{Na} 249.0733\right) .{ }^{1} \mathrm{H}$ NMR $\left(\mathrm{CDCl}_{3}, 500 \mathrm{MHz}\right)$ and ${ }^{13} \mathrm{C}$ NMR $\left(\mathrm{CDCl}_{3}, 125 \mathrm{MHz}\right)$, see Table 1 .

Xylariahgin $\mathrm{C}(\mathbf{3})$ yellow oil. $[\alpha]_{\mathrm{D}}^{24}-23.1$ (c 0.14 , $\mathrm{MeOH}$ ), UV (MeOH) $\lambda_{\max }(\log \varepsilon) 248$ (4.15), 207 (3.99) nm, IR (KBr) $v_{\max } 3395,2964,2933,1783,1732,1660$, 1422, 1384, 1157, 1103, 933, $873 \mathrm{~cm}^{-1}$. ESIMS $\mathrm{m} / z 263$ $[\mathrm{M}+\mathrm{Na}]^{+}, \mathrm{HRESIMS} \mathrm{m} / z 263.0884[\mathrm{M}+\mathrm{Na}]^{+}$(calcd for $\mathrm{C}_{12} \mathrm{H}_{16} \mathrm{O}_{6} \mathrm{Na}$ 263.0884). ${ }^{1} \mathrm{H}$ NMR (Acetone- $d_{6}, 600 \mathrm{MHz}$ ) and ${ }^{13} \mathrm{C}$ NMR (Acetone- $d_{6}, 150 \mathrm{MHz}$ ), see Table 1.

Xylariahgin D (4) yellow oil. $[\alpha]_{\mathrm{D}}^{23}-44.9$ (c 0.10 , $\mathrm{MeOH}), \mathrm{UV}(\mathrm{MeOH}) \lambda_{\max }(\log \varepsilon) 295$ (3.07), 260 (3.98) $\mathrm{nm}, \mathrm{IR}(\mathrm{KBr}) v_{\max } 2966,2934,2878,1779,1671,1618$, 1464, 1384, 1291, 1229, 1186, 1163, 1076, $984 \mathrm{~cm}^{-1}$. ESIMS $\mathrm{m} / z 233[\mathrm{M}+\mathrm{Na}]^{+}$, HRESIMS $\mathrm{m} / z, 233.0784$ $[\mathrm{M}+\mathrm{Na}]^{+}$(calcd for $\mathrm{C}_{11} \mathrm{H}_{14} \mathrm{O}_{4} \mathrm{Na} 233.0784$ ). ${ }^{1} \mathrm{H}$ NMR $\left(\mathrm{CDCl}_{3}, 500 \mathrm{MHz}\right)$ and ${ }^{13} \mathrm{C} \mathrm{NMR}\left(\mathrm{CDCl}_{3}, 125 \mathrm{MHz}\right)$, see Table 1.

Xylariahgin E (5) yellowish oil. UV (MeOH) $\lambda_{\max }(\log$ ع) $206(3.94) \mathrm{nm}, \mathrm{IR}(\mathrm{KBr}) v_{\max } 2956,2928,2856,1773$, $1745,1582,1384,1275,1174,924,765 \mathrm{~cm}^{-1}$. ESIMS $\mathrm{m} / \mathrm{z}$ $253[\mathrm{M}-\mathrm{H}]^{-}$, HRESIMS $\mathrm{m} / z 253.1081[\mathrm{M}-\mathrm{H}]^{-}$(calcd for $\mathrm{C}_{13} \mathrm{H}_{17} \mathrm{O}_{5}$ 253.1087). ${ }^{1} \mathrm{H}$ NMR $\left(\mathrm{CDCl}_{3}, 500 \mathrm{MHz}\right)$ and ${ }^{13} \mathrm{C}$ NMR $\left(\mathrm{CDCl}_{3}, 125 \mathrm{MHz}\right)$, see Table 2 .

Xylariahgin $\mathrm{F}$ (6) yellowish amorphous power. UV $(\mathrm{MeOH}) \lambda_{\max }(\log \varepsilon) 225(4.15) \mathrm{nm}, \mathrm{IR}(\mathrm{KBr}) v_{\max } 2928$, 2860, 1717, 1429, 1313, 1194, 1124, 980, 944, 765, $616 \mathrm{~cm}^{-1}$. ESIMS $\mathrm{m} / \mathrm{z} 320[\mathrm{M}+\mathrm{Na}]^{+}$, HRESIMS $\mathrm{m} /$ $z 320.1108[\mathrm{M}+\mathrm{Na}]^{+}$(calcd for $\mathrm{C}_{14} \mathrm{H}_{19} \mathrm{NO}_{6} \mathrm{Na} 320.1105$ ). ${ }^{1} \mathrm{H}$ NMR $\left(\mathrm{CDCl}_{3}, 500 \mathrm{MHz}\right)$ and ${ }^{13} \mathrm{C}$ NMR $\left(\mathrm{CDCl}_{3}\right.$, $125 \mathrm{MHz})$, see Table 2.

3-(2,3-Dihydroxypropyl)-6,8-dimethoxyisocoumarin (7): yellowish solid. $[\alpha]_{\mathrm{D}}^{24}-6.7(c 0.14, \mathrm{MeOH})$. UV $(\mathrm{MeOH}) \lambda_{\max }(\log \varepsilon) 323$ (3.74), 287 (3.72), 278 (3.77), $242(4.55) \mathrm{nm}$. IR (KBr) $v_{\max } 3416,2928,2854,1711$, $1602,1570,1457,1429,1382,1246,1217,1205,1165$, $1061 \mathrm{~cm}^{-1}$. ESIMS $\mathrm{m} / \mathrm{z} 303[\mathrm{M}+\mathrm{Na}]^{+}$, HRESIMS $\mathrm{m} / \mathrm{z}$ $303.0838[\mathrm{M}+\mathrm{Na}]^{+}$(calcd for $\mathrm{C}_{14} \mathrm{H}_{16} \mathrm{O}_{6} \mathrm{Na} 303.0839$ ). ${ }^{1} \mathrm{H}$ NMR $\left(\mathrm{CD}_{3} \mathrm{OD}, 600 \mathrm{MHz}\right)$ and ${ }^{13} \mathrm{C}$ NMR $\left(\mathrm{CD}_{3} \mathrm{OD}\right.$, $150 \mathrm{MHz}$ ), see Table 2.

Methyl 4-(hexanoylamino) benzoate (8): yellowish solid. UV (MeOH) $\lambda_{\max }(\log \varepsilon) 272(4.44) \mathrm{nm}$. IR $(\mathrm{KBr})$ $v_{\max } 2955,2930,1720,1664,1601,1534,1407,1281$,
1175, 1111, 1019, $771 \mathrm{~cm}^{-1}$. ESIMS $\mathrm{m} / \mathrm{z} 250[\mathrm{M}+\mathrm{H}]^{+}$, HRESIMS $\mathrm{m} / z 250.1439[\mathrm{M}+\mathrm{H}]^{+}$(calcd for $\mathrm{C}_{14} \mathrm{H}_{20} \mathrm{NO}_{3}$ 250.1438). ${ }^{1} \mathrm{H}$ NMR (Acetone- $d_{6}, 600 \mathrm{MHz}$ ) and ${ }^{13} \mathrm{C}$ NMR (Acetone- $d_{6}, 150 \mathrm{MHz}$ ), see Table 2 .

Acknowledgements This project was supported financially by the National Natural Science Foundation of China (81673329 and 21322204).

\section{Compliance with Ethical Standards}

Conflict of interest The authors declare no conflict of interest.

Open Access This article is distributed under the terms of the Creative Commons Attribution 4.0 International License (http://creative commons.org/licenses/by/4.0/), which permits unrestricted use, distribution, and reproduction in any medium, provided you give appropriate credit to the original author(s) and the source, provide a link to the Creative Commons license, and indicate if changes were made.

\section{References}

1. B. Schulz, C. Boyle, Mycol. Res. 109, 661-686 (2005)

2. Y.M. Xu, P. Espinosa-Artiles, M.X. Liu, A.E. Arnold, A.A. Gunatilaka, J. Nat. Prod. 76, 2330-2336 (2013)

3. W.C. Wei, P.J. Sung, C.Y. Duh, B.W. Chen, J.H. Sheu, N.S. Yang, Mar. Drugs 11, 4083-4126 (2013)

4. L.D. Sette, M.R.Z. Passarini, C. Delarmelina, F. Salati, M.C.T. Duarte, World. J. Microb. Biot. 22, 1185-1195 (2006)

5. T.S. Suryanarayanan, N. Thirunavukkarasu, M.B. Govindarajulu, F. Sasse, R. Jansen, T.S. Murali, Fungal Biol. Rev. 23, 9-19 (2009)

6. H. Yu, L. Zhang, L. Li, C. Zheng, L. Guo, W. Li, P. Sun, L. Qin, Microbiol. Res. 165, 437-449 (2010)

7. J.L. Cui, S.X. Guo, P.G. Xiao, J. Zhejiang Univ. Sci. B. 12, 385-392 (2011)

8. Y. Wang, C.C. Dai, Ann. Microbiol. 61, 207-215 (2010)

9. G.A. Strobel, Microbes Infect. 5, 535-544 (2003)

10. H.D. Sun, S.X. Huang, Q.B. Han, Nat. Prod. Rep. 23, 673-698 (2006)

11. X. Sun, W. Wang, J. Chen, X. Cai, J. Yang, Y. Yang, H. Yan, X. Cheng, J. Ye, W. Lu, C. Hu, H. Sun, J. Pu, P. Cao, Cancer Res. 77, 926-936 (2017)

12. R. Zhan, X.N. Li, X. Du, W.G. Wang, K. Dong, J. Su, Y. Li, J.X. $\mathrm{Pu}$, H.D. Sun, J. Nat. Prod. 76, 1267-1277 (2013)

13. W.G. Wang, A. Li, B.C. Yan, S.B. Niu, J.W. Tang, X.N. Li, X. Du, G.L. Challis, Y.S. Che, H.D. Sun, J.X. Pu, J. Nat. Prod. 79, 149-155 (2016)

14. B.C. Yan, W.G. Wang, D.B. Hu, X. Sun, L.M. Kong, X.N. Li, X. Du, S.H. Luo, Y. Liu, Y. Li, H.D. Sun, J.X. Pu, Org. Lett. 18, 1108-1111 (2016)

15. J.W. Tang, W.G. Wang, A. Li, B.C. Yan, R. Chen, X.N. Li, X. Du, H.D. Sun, J.X. Pu, Tetrahedron 73, 3577-3584 (2017)

16. J. Rivera Chavez, M. Figueroa, M.D. Gonzalez, A.E. Glenn, R. Mata, J. Nat. Prod. 78, 730-735 (2015)

17. J.C. Chang, G. Hsiao, R.K. Lin, Y.H. Kuo, Y.M. Ju, T.H. Lee, J. Nat. Prod. 80, 38-44 (2017)

18. Q. Zhang, J. Xiao, Q.Q. Sun, J.C. Qin, G. Pescitelli, J.M. Gao, J. Agric. Food Chem. 62, 10962-10969 (2014) 
19. H.B. Bode, B. Bethe, R. Hofs, A. Zeeck, ChemBioChem 3, 619-627 (2002)

20. K.P. Haval, N.P. Argade, J. Org. Chem. 73, 6936-6938 (2008)

21. T. Nakazawa, K. Ishiuchi, A. Praseuth, H. Noguchi, K. Hotta, K. Watanabe, ChemBioChem 13, 855-861 (2012)

22. V.H. Deshpande, B. Rai, R.A. Khan, Tetrahedron 52, 7159-7162 (1996)

23. A. Saeed, M. Qasim, Nat. Prod. Res. 28, 185-190 (2014)

24. A. Bombrun, U. S. Patent 10/493, 066, 24 Feb 2005

25. N. Zheng, F.H. Yao, X.F. Liang, Q. Liu, W.F. Xu, Y. Liang, X.B. Liu, J. Li, R.Y. Yang, Nat. Prod. Res. 32, 755-760 (2018)

26. O.F. Smetanina, A.N. Yurchenko, E.V. Ivanets, A.V. Gerasimenko, P.T.H. Trinh, B.M. Ly, N.D. Nhut, T.T.T. Van, E.A.
Yurchenko, S.S. Afiyatullov, Chem. Nat. Compd. 53, 600-602 (2017)

27. A. Monks, D. Scudiero, P. Skehan, R. Shoemaker, K. Paull, D. Vistica, C. Hose, J. Langley, P. Cronise, A.V. Wolff, M.G. Goodrich, H. Campbell, J. Mayo, M. Boyd, J. Natl. Cancer 83, 757-766 (1991)

28. M. Zhou, K. Zhou, X.M. Gao, Z.Y. Jiang, J.J. Lv, Z.H. Liu, G.Y. Yang, M.M. Miao, C.T. Che, Q.F. Hu, Org. Lett. 17, 2638-2641 (2015)

29. M. Zhou, M.M. Miao, G. Du, X.N. Li, S.Z. Shang, W. Zhao, Z.H. Liu, G.Y. Yang, C.T. Che, Q.F. Hu, X.M. Gao, Org. Lett. 16, 5016-5019 (2014)

30. L.J. Reed, H. Muench, Am. J. Hyg. 27, 493-497 (1938) 